\title{
The Information Systems of Boarding House Search Application in Soegijapranata Catholic University Semarang Based On Android
}

\author{
Anastasia Widiastuti, Erdhi Widyarto Nugroho, Albertus Dwi Yoga Widiantoro \\ Department of Information System, Faculty of Computer Science, \\ Soegijapranata Catholic University, Semarang, Indonesia \\ anastasiawidi30@gmail.com, erdhi@unika.ac.id, yoga@unika.ac.id
}

\begin{abstract}
Soegijapranata Catholic University is one of the private universities that exist in Semarang. Many students from outside the region are on their education at this university. Students from outside the area seek for the temporary residence or domicile or are often referred to as boarding houses. The increasing of the development technology makes it easier for humans to find all the information. Boarding houses search application helps facilitate students in finding information about boarding houses which are desired. This application can be operated on Android and there are printed the profiles and the facilities of boarding houses, so that users can use them easily, and equipped with GPS to find boarding houses locations, it is not easier to find the locations of the boarding houses. From the results of this study, 90\% agree with the existence of a boarding houses search application. This application is very beneficial for various parties such as boarding houses managers can promote their own boarding houses and students are easier to find boarding houses information which is desired and they can choose from the lowest price to the highest price.
\end{abstract}

Keyword - boarding houses, android, GPS

\section{INTRODUCTION}

Based on case studies at Soegijapranata Catholic University area. There is a number of students from various regions come from outside the area of Semarang are studying at Soegijapranata Catholic University. Students from various regions really need a safe and comfortable place to stay such as boarding houses, so that, they'll feel comfortable living in a boarding house. The people who are looking for a boarding house find it difficult when looking for it. They searching for boarding houses by the door to door, asking acquaintances or the surrounding community, and looking at brochures from nowhere to get information about boarding houses, but this method is very ineffective because it will waste more time and energy and will damage the environment. While the amount of boarding houses availability is sometimes not comparable with the number of people looking for boarding houses. In the other hand, the seeker is confused and must immediately get a place to live. In addition, boarding houses seekers also cannot see the conditions in the boarding houses, whether it's price, room availability, or the facilities provided. From the existing problems, it can be concluded that how difficult it is for students to find a safe and comfortable place to live. This fact is a problem that is currently faced. So, with the development of technology that exists at the present time, the author is interested in creating a boarding house search application in the area of Soegijapranata Catholic University. The making of this application is very helpful for students because there is no boarding houses search application base on Android. At least, it gives a positive value to the community of smartphone users in order to be able to use the smartphone well and beneficially.

\section{LITERATURE REVIEW}

\section{A. Literature Review}

A mobile application is a software that runs on a mobile device such as a smartphone or tablet PC. Mobile applications are also known as applications that are downloaded and have their own functions. This function can add 
functionality from the mobile device itself. To have the desired cellular application, users can download through certain sites with their own operating system. Google Play and iTunes are some examples of sites that provide various applications for Android and iOS users to download applications [4].

Information becomes something very valuable in the internet world. With the help of internet media, the exchange of information is faster and it is also used for the dissemination of information in the form of advertisements from various employment sectors such as the tourism sector. Hotels are one of the most sought- after tourism sectors for information by foreign and local tourists. To publish information, a hotel can use a media website that is currently generally made in the form of a CMS (Content Management System) that is integrated and easy to maintain. To have a hotel CMS website, we can use CMS which is provided on the internet that is free and open source. Many plug-ins that already exist in it, so users only need to do the installation process and settings which can be done easily with the help of complete documentation. The problem that arises is that the CMS application developed is quite timeconsuming. With the existence of journals and literature reviews, researchers conduct research by making an analysis and design of hotel information systems that are used to build hotel information system applications for data processing hotel to make it easy. The research will be conducted at Graha Prima Pacitan Hotel [2].

\section{B. Boarding House}

Boarding houses are a business engaged in room rentals or residences and equipped with facilities that have been provided. The term boarding house is very related to students because in general boarding houses are rented out to students although sometimes it rented out to the public. Boarding houses are very various and can be seen from the way of rentals, facilities and prices vary. Boarding houses are a promising investment that can be calculated either per month or quarterly [1].

\section{Hotels}

Hotels are one of the most sought-after tourism sectors for information by foreign and local tourists. Hotel is a building that provides rooms aimed at guest accommodation services, both individuals and groups of people, equipped with food, drinks, and facilities, according to the technological developments available in the hotel. Hotels are managed professionally for profit [2].

\section{Tourism}

Tourism is a journey from one place to another that is temporary, carried out by individuals or groups, as an effort to find balance and happiness with the environment in social, cultural, natural and scientific dimensions. Furthermore, according to Musanef (1995, h.11) tourism is a journey that is carried out temporarily, which is carried out from one place to another to enjoy trips for picnic and recreation [3].

\section{E. Information Systems}

Information system is a system that provides information needed by all levels of management in making decisions or policies, and runs operations from a combination of people, information technology, and organized procedures, which are interconnected, which collect the data, process, store, and distribute the information with the same intention, to achieve a goal provided by a company or business entity that is useful for management [5].

An information system is an organizational system that brings together the needs of daily transaction processing, supports operations, managerial, and a strategy of an organization in providing certain reports needed by outsiders. Information System is an organized data collection of hardware, software, and personnel to obtain, store, repair, manipulate, analyze, and display all data in the form of information [1].

According to Soeherman (2008:5), Information systems are a series of data that are managed into a form that is meaningful and can be accepted and utilized, in the form of procedures, data, the technology used to carry out a process that produces valuable information for decision making. The 
information system is very inherent and is an infrastructure that supports success for each organization (in achieving its objectives) [6].

\section{F. Android}

Android is an operating system for mobile devices based on Linux that includes middleware and application operations. Android provides a platform that is open for developers to create new applications. Initially, Google bought Android which was a newcomer who made software for cell phones/smartphones. Android is a new generation of mobile platforms that provide free source code for application developers so that applications can run on Android. The underlying operating system for Android is distributed under the Apache Software license [7].

Android OS is an operating system based on Linux and an open source operating system. In addition to Android as a Software Development Kit (SDK) for application development, Android is also available free in the form of an operating system. This causes smartphone vendors to be interested in producing smartphones and tablet computers based on Android. And now Android has spread widely on tablet computers, not only on smartphones [8].

AVD (Android Virtual Device) is an emulator for running Android applications. Each AVD consists of a hardware profile that governs the choice of the emulator's hardware features. For example, determine whether to use a camera device, whether to use a physical QWERTY keyboard or not, how much internal memory, etc. AVD also has an Android version mapping where we determine the version of the Android platform to run on the emulator. Another choice of AVD, for example, is to determine the skin to be used on the emulator, which allows determining the screen dimensions, appearance, and much more. And also can determine the virtual SD Card to be used emulator [7].

\section{G. Firebase}

Firebase is a provider of real-time databases and backend as a service. This service provides an application development
API that allows data applications to be synchronized on the client and stored on the Firebase Cloud. Firebase provides a library for various client platforms that allow integration with Android. IOS, JavaScript, Java Objective-C, and Node Js applications can be called DbaaS services (Database as a Service) with a real-time concept. Firebase is used to facilitate the addition of features that will be built by the developer [9].

Firebase has a complete library for the web and mobile platforms and can be combined with various frameworks such as nodes, Java, JavaScript, AngularJS, and others. Application Program Interfaces (API) for storing and synchronizing stored data as bits in JSON form on the cloud and synchronized in real-time. Firebase is used to store received data. Firebase is also needed to provide cloud storage services that allow middleware to be combined with application interfaces from other parties. Firebase is very possible to develop mobile and web applications that can be used to generate data in real-time [10]. The following services provided by Firebase:

\section{Firebase Storage}

Firebase Storage is used to store data such as images, audio, and video. Some applications must use image, audio or video files. Firebase Storage makes it easy to upload and download for applications.

\section{Real-time Database}

Useful for storing and synchronizing data between users and devices in real-time using a cloud-hosted NoSQL database. Real-time is the operating condition of a hardware or software system that is limited by clear deadlines and relative to time.

\section{Cloud Messaging}

Useful for storing and sharing images, audio, videos, or other content that users easily create with reliable, simple, and costeffective object storage developed for google scale [11].

\section{H. Google Maps API}

Google Maps API is a service that is owned by Google, which can be accessed for free. Google Map is a map of the world that can be used to see all regions on earth using a browser. Google Map API has a library that is 
formed from JavaScript. Google maps are developed with JavaScript, HTML services, while maps have been provided by Google in order for developers to focus more on the data displayed. In other words, developers only make data, while maps have been provided by Google, so developers are not troubled by making a map of a location [12].

Google Maps API is a service to integrate Google Maps on pages of sites developed independently. This API provides functions to manipulate maps and add content to the map. This service is developed in several versions such as JavaScript and Flash [13].

Google Map can be developed with a database. All data related to the location point, stored in the table and can be displayed as desired by the user. Fill in the table that contains map position data, can be displayed by presenting location information using Google Map. Users will certainly get more detailed information, especially information on the location of tourist attractions, companies or agencies [14].

\section{GPS (Global Positioning System)}

Global Positioning System (GPS) is a satellite navigation system that provides information on location, time and weather conditions on the surface of the earth as long as it still connected with GPS signals that are transmitted by satellite. In addition, GPS is also used to provide information on the position of the surface of the earth. All activities related to the location and position on the earth's surface can be assisted by GPS [15].

GPS is also an application provided by Google. GPS is a global map where users can find locations in the world, while GPS locations can be made by users according to their needs [16].

GPS enables users on land, sea, and air to determine the position in three dimensions, speed, and time 24 hours every day, in any weather conditions anywhere in the world [13].

\section{METHOD}

\section{A. Application Development Methods}

At this stage, the author collects secondary data that can support primary data for the development of this application. The application development process starts with the boarding houses search designs. Design the form to fill in the data needed on the board, design the database forms, and programming. This method allows complex development solutions to be more logical with easy steps, so it can be a product that is ready for use. The next step taken by the author is to test the application when filling out the questionnaire to the respondents who have been determined. The diagram below is the flow of the design of a boarding house search application.

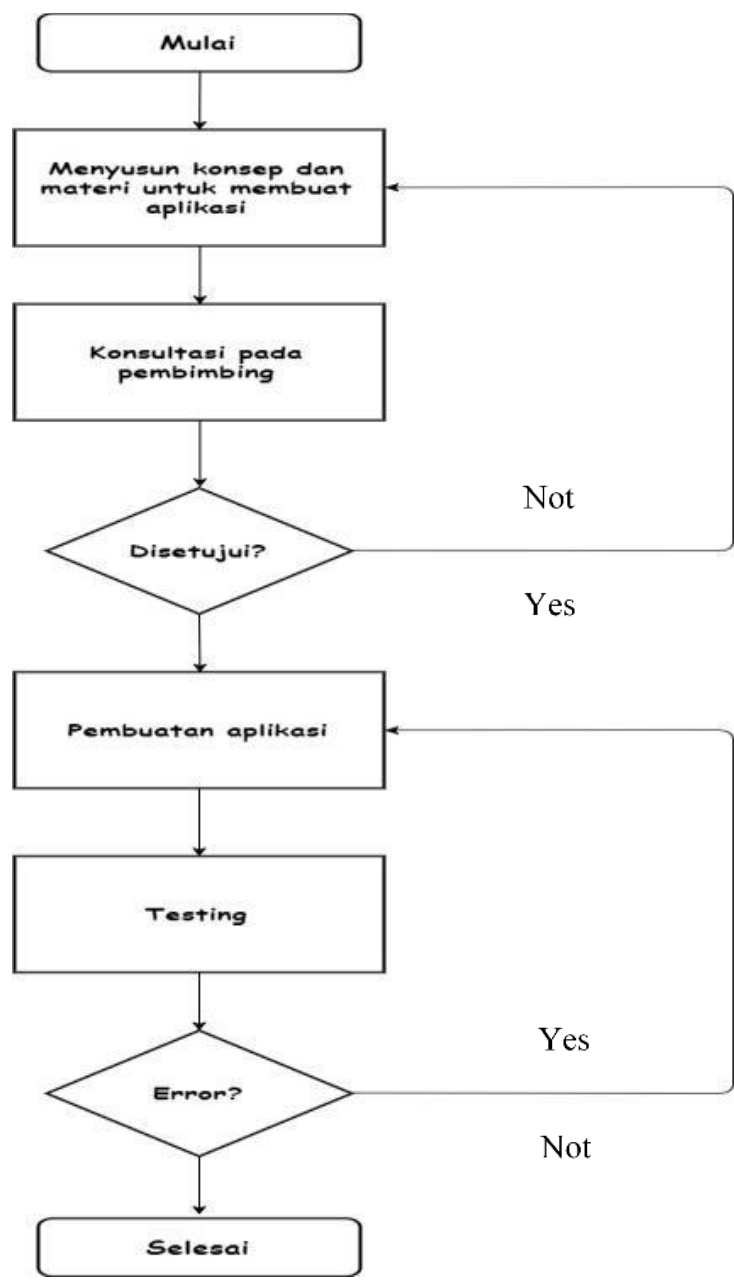

Figure 1. draft application design 
B. Research Populations and Samples

In this study, 30 samples of students were taken from Soegijapranata Catholic University from outside the island and 10 samples from boarding house owners.

\section{Data Collection Techniques}

Data collection techniques are as follows:

1. Questionnaire a technique of collecting data by giving a set of written questions to the respondent.

2. Environmental Survey a data collection technique carried out by the author by observing the surrounding environment to obtain information at the time of the study.

\section{Data Sources}

Data sources are divided into 2 types, primary data sources, and secondary data sources. Primary data sources are sources of data obtained directly from original sources and not through intermediaries from other people. Secondary data sources are sources of data obtained indirectly or through intermediaries.

1. The primary data source is obtained through a distributed questionnaire.

2. Secondary data sources are obtained by reading articles and so on.

E. Research Instrument

1. Websites and applications are obtained from surveys and questionnaires given to the boarding house owners and boarding house seekers.

2. Questionnaire as a final result of the comparison whether the making of this application was successful.

\section{F. Frame of Mind}

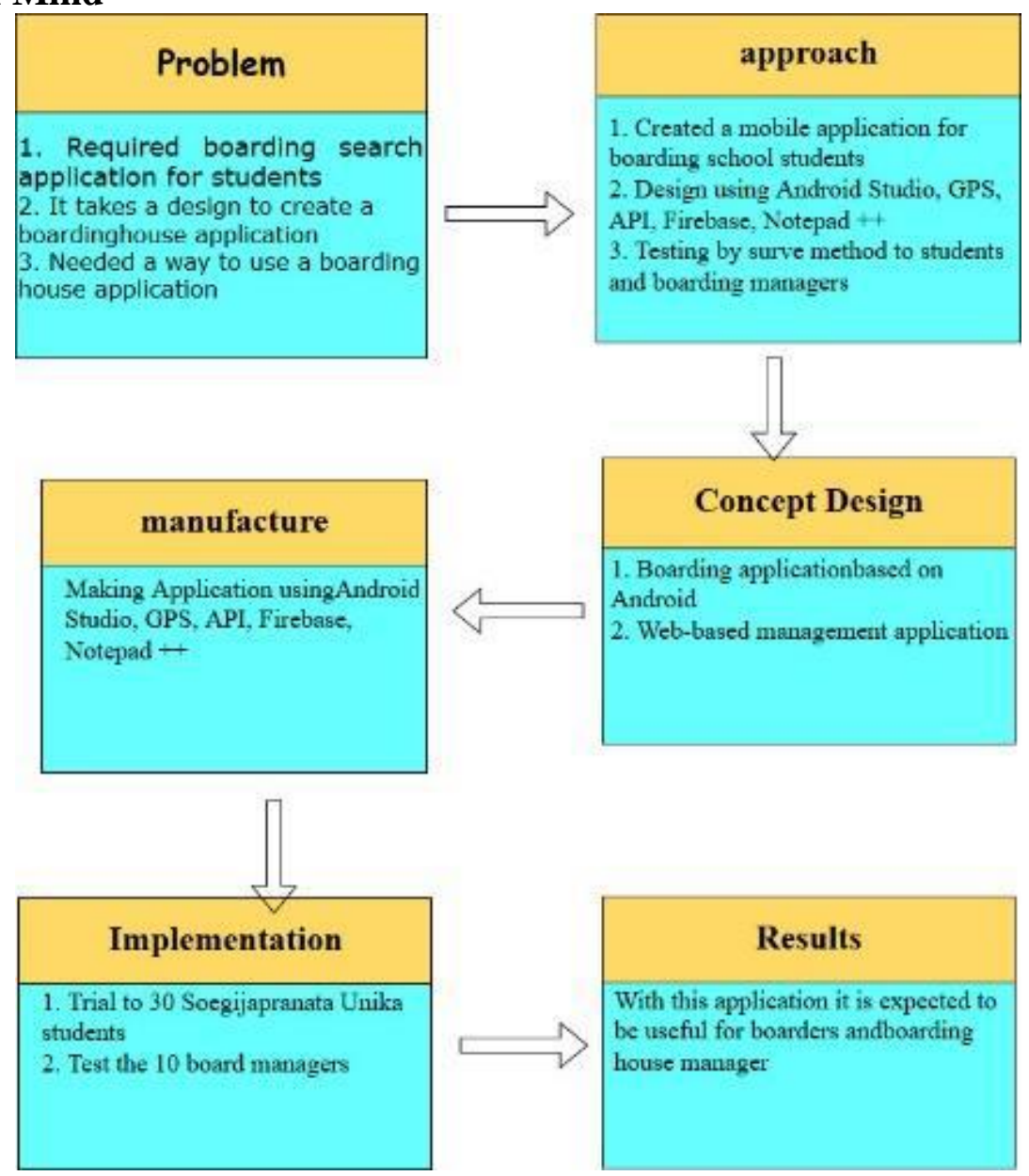

Figure 2. Frame of mind 


\section{RESULT AND DISCUSSION \\ A. Use Case Diagram}

Use case diagram will explain the functions that will be done by the system. The diagram below explains that the use case diagram will present the interaction between the user and the system.

1. Use case diagram users and manager.

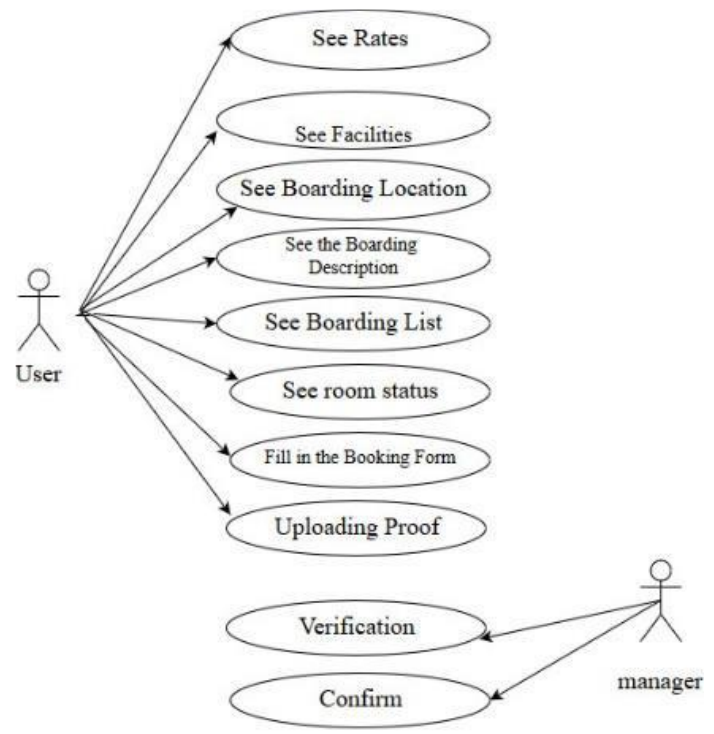

Figure 3. Use case diagram user and manager

2. Use case diagram admin and manager.

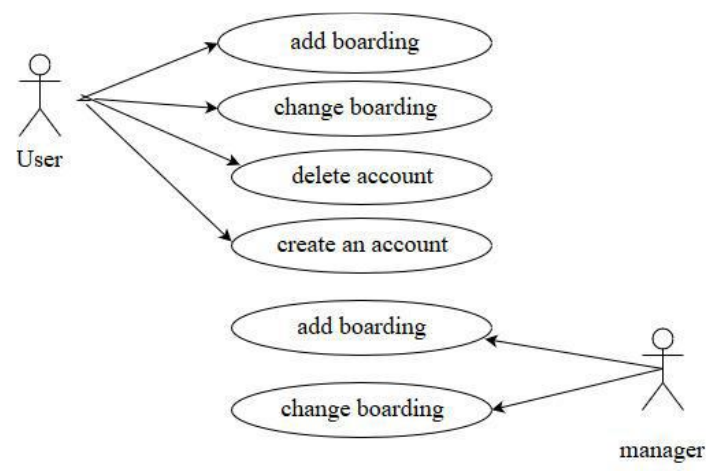

Figure 4. Use case diagram admin and manager

\section{B. Flowchart}

A flowchart is a flow chart in a program or procedure logically usable for communication and documentation tools.

Flowchart for boarding houses seekers.

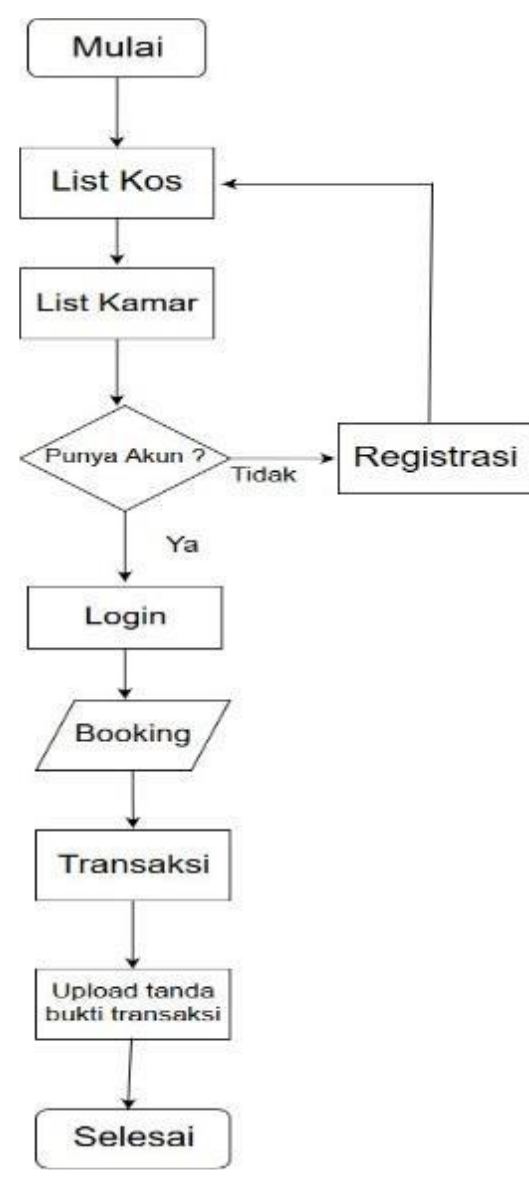

Figure 5. Flowchart for boarding house seekers

\section{ER Diagram}

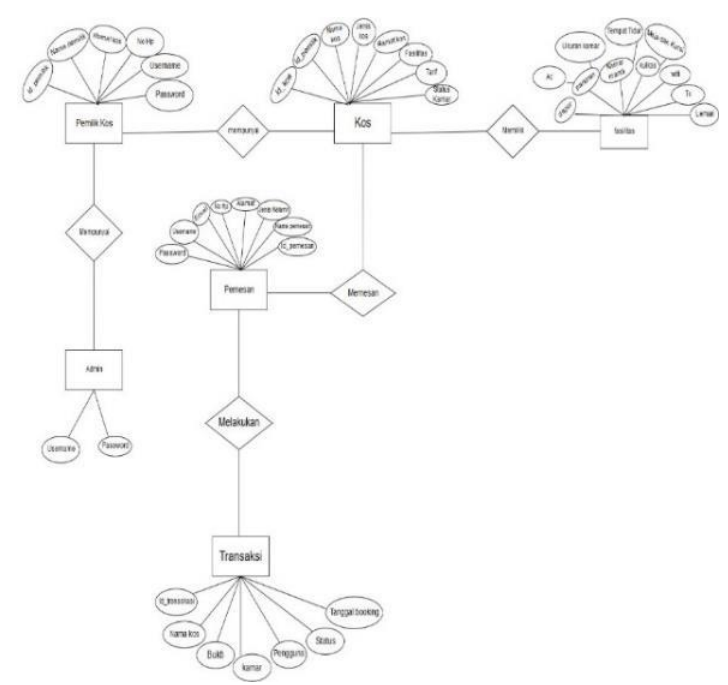

Figure 6. diagram ER

\section{Application Testing}

Application testing is done by distributing questionnaires to 40 respondents. 30 questionnaires are distributed to respondents who are the users of the application, then 10 other questionnaires are distributed to board 
managers who have tried the application to and easy to use. The following are the results find out whether this application is feasible of the application testing phase.

1. The results table of 10 respondents of the boarding house manager. Applications that are made can be used easily with a high percentage value.

Table 1. percentage of boarding house manager questionnaires

\begin{tabular}{|c|l|l|l|}
\hline No & \multicolumn{1}{|c|}{ Information } & \multicolumn{1}{c|}{ Yes } & \multicolumn{1}{c|}{ Percentage (\%) } \\
\cline { 3 - 4 } & & \multicolumn{1}{c|}{ Not } & 0 \\
\hline 1 & The application can be used & 60 & 40 \\
\hline 3 & The application is easy to use & 10 \\
\hline 4 & $\begin{array}{l}\text { The application is useful for managing } \\
\text { boarding houses }\end{array}$ & 90 & 0 \\
\hline 5 & $\begin{array}{l}\text { The application contains the existing of } \\
\text { boarding house information }\end{array}$ & 100 & 10 \\
\hline
\end{tabular}

2. The results table of 30 boarding house seekers respondents.

Table 2. percentage of boarding house seekers questionnaire

\begin{tabular}{|c|c|c|c|c|}
\hline \multirow[t]{2}{*}{ No } & \multirow[t]{2}{*}{ Information } & \multicolumn{3}{|c|}{ Percentage (\%) } \\
\hline & & $\mathbf{S A}$ & $\mathbf{D}$ & $\mathbf{A}$ \\
\hline 1. & $\begin{array}{l}\text { The application helps students in finding } \\
\text { boarding houses. }\end{array}$ & 56,7 & 0 & 36,7 \\
\hline 2. & $\begin{array}{l}\text { The information provided by the application is } \\
\text { understandable }\end{array}$ & 33,3 & 10 & 56,7 \\
\hline 3. & $\begin{array}{l}\text { The application provides accurate } \\
\text { information. }\end{array}$ & 33,3 & 0 & 63,3 \\
\hline 4. & Satisfying application in seeking information & 23,3 & 0 & 70 \\
\hline 5. & Ability and function as expected. & 20 & 0 & 76,7 \\
\hline 6. & $\begin{array}{l}\text { The color display in the application is pleasing } \\
\text { to the eye }\end{array}$ & 23,3 & 13,3 & 60 \\
\hline 7. & $\begin{array}{l}\text { The use of menus and menu application } \\
\text { features is easy to use. }\end{array}$ & 36,7 & 0 & 56,7 \\
\hline 8. & Applications is easy to learn. & 46,7 & 0 & 53,3 \\
\hline 9. & Applications is easy to operate. & 33,3 & 0 & 66,7 \\
\hline 10. & $\begin{array}{l}\text { The display in the application is easily } \\
\text { recognizable. }\end{array}$ & 30 & 0 & 70 \\
\hline 11. & Readable application & 36,7 & 0 & 63,3 \\
\hline 12. & The symbols are easily understood images & 26,7 & 0 & 66,7 \\
\hline 13. & $\begin{array}{l}\text { Easy to access the information about the } \\
\text { products offered. }\end{array}$ & 33,3 & 0 & 66,7 \\
\hline 14. & $\begin{array}{l}\text { The specification of applications offered as } \\
\text { needed }\end{array}$ & 23,3 & 10 & $66,7_{[1]}$ \\
\hline
\end{tabular}


A. Conclusions

\section{CONCLUSION}

The conclusions obtained by the author in making the application "THE INFORMATION SYSTEMS OF BOARDING HOUSE SEARCHING IN SOEGIJAPRANATA CATHOLIC UNIVERSITY SEMARANG BASED ON ANDROID " as follows:

1. This design is based on the facilities needed by boarding house seekers and boarding house managers for example such as boarding house lists around SCU equipped with detailed information of boarding house description, boarding house type, cellphone number of boarding house owner, price per room, facilities, location, also pictures as instructions for boarding house seekers to book boarding house rooms.

2. The design needed to make this application is a design that makes it easier for students to find boarding houses and makes it easier for boarding houses managers to promote their boarding house. Making this application uses Android studio, GPS, Google Map API, Firebase, and Notepad ++.

3. After a survey of 30 respondents of boarding house seekers and 10 respondents boarding house owners, this application is very helpful and useful for boarding house seekers, this application provides accurate information, this application is easy to use, and the symbols are easy to read. This application is also easily accessible by boarding house owners, easy to understand and useful for boarding house owners to manage their boarding house businesses. It can be concluded that this boarding house search application is very useful and makes it easy for boarding house seekers and boarding house owners.

\section{B. Suggestions}

In making this application, there are many disadvantages. There are also some constructive suggestions for continuing the research as follows:

1. Boarding house search applications can be expanded more widely such as adding the boarding houses lists. The applications can input data management using Android.

2. Boarding houses search application can be added by expanding its coverage area.

3. Added the chat feature in this application.

\section{REFERENCES}

[1] J. Sistemasi, "Usman, Aplikasi Pencarian Lokasi Kos Di Kota Tembilahan Berbasis Web Mobile 38," vol. 7, pp. 38-47, 2018.

[2] L. Kusumawardani and I. U. Wardati, "Analisis Dan Perancangan Sistem Informasi Hotel Graha Prima Pacitan," vol. 6, no. 3, pp. 26-31, 2014.

[3] R. Sefira Ryalita Primadany, Mardiyono, "Analisis Strategi Pembangunan Pariwisata Daerah (Studi pada Dinas Kebudayaan dan Pariwisata Daerah Kabupaten Nganjuk)," vol. 1, no. 4, pp. 135-143.

[4] A. P. Kelas, M. Teknologi, and F. Prayoga, "Jurnal skripsi," pp. 1-19.

[5] D. Rosadi and F. O. Andriawan, "Aplikasi sistem informasi pencarian tempat kos di kota bandung berbasis android," vol. 10 , no. 1, pp. 50-58, 2016.

[6] R. Ariyanti and I. Kanedi, "Pemanfaatan Google Maps API pada Sistem Informasi Geografis Direktori Perguruan Tinggi di Kota Bengkulu," vol. 11, no. 2, pp. 119-129, 2015.

[7] A. Sinsuw and X. Najoan, "Prototipe Aplikasi Sistem Informasi Akademik Pada Perangkat Android," pp. 1-10, 2013.

[8] I. W. Gede, S. Wijaya, J. J. A. Yani, and J. Timur, "Penerapan We Service pada Aplikasi Sistem Akademika pada Platfrom Sistem Mobile Android," pp. $1-6$. 
[9] R. Tanone, U. Kristen, and S. Wacana, "Penerapan Firebase Realtime Database Pada Prototype Aplikasi Pemesanan Makanan Berbasis Android," no. December, 2018.

[10] A. Sonita and R. F. Fardianitama, "Aplikasi E - Order menggunakan Firebase Dan Algoritma Knuth," vol. V, no. September, pp. 38-45, 2018.

[11] M. Ilhami, "Pengenalan Google Firebase Untuk Hybrid Mobile Apps Berbasis Cordova," vol. 3, no. 124, pp. 16-29, 2017.

[12] “Optimasi_Rute_Sales_Coverage Menggunakan.pdf"

[13] I. M. O. Widyantara, I. G. Agus, and K. Warmayana, "Penerapan Teknologi GPS Tracker Untuk Identifikasi Kondisi Traffik Jalan Raya," vol. 14, no. 1, pp. 31-35, 2015.

[14] M. Adibhadiansyah, "Pengembangan Sistem Informasi Kos Berbasis Android," Manaj. Inform., vol. 5, pp. 68-73, 2016.

[15] F. C. Permana, D. Chaerani, and E. Paulus, "Implementasi Cell ID Dan GPS Dalam Pencarian Lokasi Fasilitas Kesehatan Terdekat," vol. 13, no. 1, pp. 52-62, 2017.

[16] W. Ahmad, A. Zia, and U. Khalid, "A Google Map Based Social Network (GMBSN) for Exploring Information about a Specific Territory," vol. 2013, no. July, pp. 343-348, 2013. 